\title{
Serum IgE in Asthmatic Children
}

\section{Relation to Age, Sex, Eczema, and Skin Sensitivity Tests}

\author{
C. B. S. WOOD and J. OLIVER \\ From the Department of Child Health, University of Bristol
}

\begin{abstract}
Wood, C. B. S., and Oliver, J. (1972). Archives of Disease in Childhood, 47, 890. Serum IgE in asthmatic children: relation to age, sex, eczema, and skin sensitivity tests. A simple method was used to detect raised serum concentrations of IgE immunoglobulin in 237 asthmatic children. The lower limit of sensitivity of the method was 900 units $/ \mathrm{ml}$. $49 \%$ of the children were found to have concentrations of 1000 units $/ \mathrm{ml}$ or over. Among those who had asthma and either past or present eczema, $66 \%$ had IgE concentration over 1000 units $/ \mathrm{ml}$, but among those with asthma alone, only $35 \%$ had IgE levels of 1000 units $/ \mathrm{ml}$ or more. A level of 900 units/ml was chosen to discriminate between high and low IgE groups since this level is probably near to the mean $+2 S D$ for normal children.

The results of repeated sampling for 50 of the children suggested that those with high IgE concentrations and those with normal IgE concentration form stable subgroups. In those under 5 years old, high levels of IgE were uncommon. Skin (prick) tests were positive in $92 \%$ of the children, and a larger number of positive tests were found in children with high IgE concentration.
\end{abstract}

The discovery in man that many reaginic antibodies reside in a separate class of immunoglobulin -IgE-(Ishizaka, Ishizaka, and Hornbrook, 1966) and that raised serum concentrations of IgE occur in allergic asthmatics (Johansson and Bennich, 1967) and in children with asthma and eczema (Berg and Johansson, 1969b), makes it possible to approach childhood asthma with a new objective yardstick for allergic sensitization.

IgE concentrations were measured by Johansson, Bennich, and Wide (1968) by the radio immunosorbent technique, a highly sensitive and sophisticated technique which is not yet generally available. In 1969, Rowe adapted the single radial diffusion method for protein measurement of Mancini, Carbonara, and Heremans (1965) in order to increase its sensitivity by applying a 131 I-labelled anti-sheep antibody to the radial diffusion plate. Sera from 50 Bristol children with asthma were studied by this method, and approximately half of those with prominent allergic features were found to have increased concentrations of IgE (Rowe and Wood, 1970). In the present report the single radial diffusion method has been modified by the appiication of a similar second antibody

Received 24 April 1972. stage, but without the use of isotope labelling. The sensitivity of the method is considerably less than that of Rowe, but it has been found suitable for reliably measuring IgE concentration of over 900 units/ml (the units referred to in this paper are those of the Research Standard (Rowe et al., 1970) in which 1 unit of $\operatorname{IgE}$ is approximately equivalent to $1 \mathrm{ng}$ ).

In normal children, Berg and Johansson (1969a) have shown that IgE concentrations increase with age, and Johansson (1968) has reported an average normal adult level of $280 \mathrm{ng} / \mathrm{ml}$ and a range of \pm 2 logarithmic standard deviations of from $61 \cdot 4$ to $1000 \mathrm{ng} / \mathrm{ml}$. The method, now described, may be used, therefore, to detect and measure significantly raised levels.

\section{Materials and Methods}

Collection and storage of sera. Venous blood was collected from 236 children aged from 6 months to 15 years who were either inpatients or outpatients at Bristol Royal Hospital for Sick Children between December 1968 and December 1971, and who were considered to have asthma irrespective of clinical opinions as to its aetiology. None was on long-term corticosteroid treatment. From a large panel of sera from nonasthmatic patients 64 fresh samples were also examined. All sera were separated at room temperature 
and then stored at $-20{ }^{\circ} \mathrm{C}$ before testing. Wherever possible each was tested within 3 to 4 weeks of being taken. In a number of cases repeated samples were obtained over a period of 18 months. A subsample of the sera was also tested after repeated freezing and thawing.

IgE determinations. Radial diffusion plates were made as follows. For each plate $0.1 \mathrm{ml}$ anti- $\mathrm{IgE}$ antiserum (Lot 8930 ) was mixed with $10 \mathrm{ml}$ of a solution of $1.5 \%$ Noble Agar in $0.3 \mathrm{M}$ potassium phosphate buffer at $p \mathrm{H} 8$. The agar was allowed to cool to $54^{\circ} \mathrm{C}$ before the antiserum was added and the mixture was then poured into a $5 \mathrm{~cm} \times 8 \mathrm{~cm}$ plate after the method of Mancini et al. (1965). After about 4 hours, wells $2.4 \mathrm{~mm}$ in diameter and $1.5 \mathrm{~cm}$ apart were cut. The agar was $1.0 \mathrm{~mm}$ thick and the volume of each well was $5 \mu 1$. The sera to be tested were then inserted into the wells, each of which was filled 3 times, so that the total volume inserted into each was $15 \mu \mathrm{l}$. The sera soaked into the agar between each filling over 2 to 3 hours. Dilutions of the research standard for $\mathrm{IgE}$ (Batch 68/341) were inserted in a similar way in concentrations of $2 \cdot 5 \%, 5 \%, 10 \%, 20 \%, 30 \%, 40 \%, 50 \%$ of the standard. The concentration of $\mathrm{IgE}$ in the undiluted standard was 9346 units $/ \mathrm{ml}$ so that $10 \%$ of standard contained approximately 900 units $/ \mathrm{ml}$ and the dilution ranged from 225 units $/ \mathrm{ml}$ to 4600 units $/ \mathrm{ml}$. The plate was placed in a Gallenkamp cool incubator at $15-20^{\circ} \mathrm{C}$, and after 24 hours the diameter of the precipitation rings round each well measured with a graduated eye-piece. The plate was then washed in changes of phosphate buffered saline at $p \mathrm{H} 7 \cdot 4$ for one week. After the last wash surplus saline was drained off from the wells with a Pasteur pipette until they ceased to refill by seepage. Each well was then filled with $5 \mu \mathrm{l}$ rabbit anti-sheep serum (Behringwerke) diluted 1 in 2 with phosphate buffered saline. The plate was returned to the cooled incubator for a further 24 hours after which the precipitation rings were remeasured with a graduated eye-piece.

Plotting the square of the diameter of the precipitation rings against concentration of standard IgE solutions inserted into the wells resulted in a straight line graph both before and after the addition of the rabbit antisheep antibody (Fig. 1). However, after the second antibody had been added it was possible to see the precipitation rings for the IgE standards of approximately 900 units $/ \mathrm{ml}$ and 450 units $/ \mathrm{ml}$. The concentrations of unknown sera could be reliably read from the graph at levels 900 units $/ \mathrm{ml}$ and upwards.

In order to assess the reproducibility of the method after the addition of the second antibody, the coefficients of variation and $95 \%$ confidence limits for 6 blind replications of 4 fresh sera were assessed as indicated in Table I.

Sera from a group of 33 asthmatic children were examined both by the method described above and by the radio radial diffusion method (Rowe, 1969). In the 12 samples with concentrations over 900 units $/ \mathrm{ml}$, the correlation coefficient for the two methods was 0.924 ,

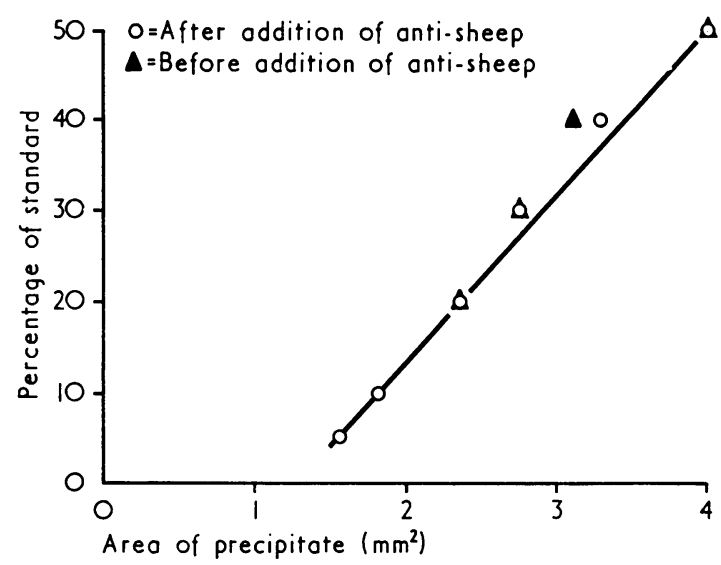

FIG. 1.-Relation between IgE concentration (percentage of standard) and the area of precipitate in agar plate before and after the addition of anti-sheep antibody.

TABLE I

Reproducibility of IgE Determinations

\begin{tabular}{c|c|c}
\hline $\begin{array}{c}\text { Average of } \\
6 \text { Replications } \\
\text { (units/ml) }\end{array}$ & $\begin{array}{c}\text { Coefficient } \\
\text { of } \\
\text { Variation }\end{array}$ & $\begin{array}{c}95 \% \\
\text { Confidence } \\
\text { Limits }\end{array}$ \\
\hline 1200 & 0.0799 & $1200 \pm 100$ \\
2300 & 0.0491 & $2300 \pm 120$ \\
2800 & 0.0288 & $2800 \pm 80$ \\
4600 & 0.0201 & $4600 \pm 90$ \\
\hline
\end{tabular}

indicating a high degree of correlation $(P<0.01)$ (Fig. 2). Those with concentrations below 900 units $/ \mathrm{ml}$ could not reliably be measured unless a labelled antibody was used.

Skin tests. Skin tests were performed by a modified prick method on the volar surface of the forearm or the back using 21-gauge needles and test solutions manufactured by Bencard (Beecham Group Ltd.) and Dome (Miles Laboratories). A positive result was recorded if a raised wheel appeared within 15 minutes which was equal to or larger than $2 \mathrm{~mm}$ in diameter. Many reactions were much stronger, and all were surrounded by a flare. Table II indicates the solutions used on each child.

Statistical methods. Confidence limits, coefficients of variation, correlation coefficient, Student's ' $t$ ' test, $\chi^{2}$, and Wilcoxon's ranking test were calculated by routine methods. The use of statistical methods dependent on the normal distribution has had to be limited, however, because the method of IgE measurement has a definite threshold. IgE concentrations have been corrected to the nearest 100 units/ml except where confidence limits are stated. 


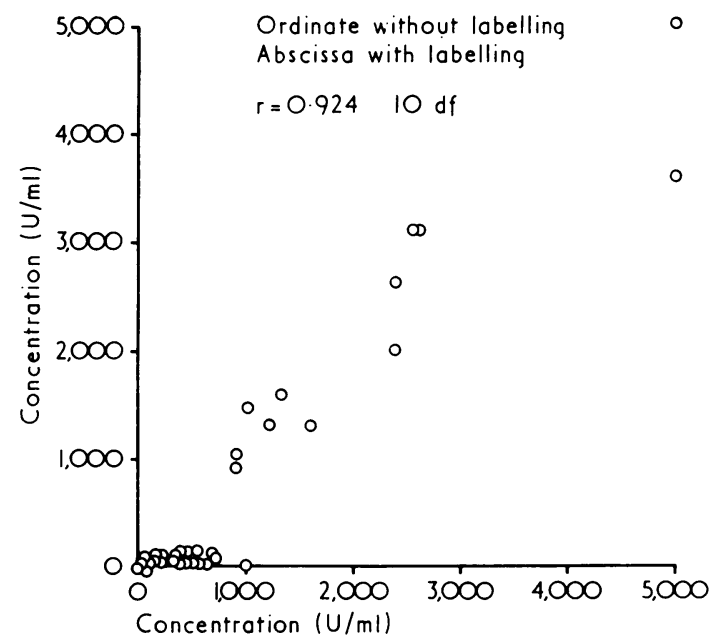

FIG. 2.-Correlation between IgE determinations on same samples with and without ${ }^{131} \mathrm{I}$ labelling of anti-sheep antibody.

TABLE II

Allergens Applied

\begin{tabular}{|c|c|c|c|}
\hline Pollens & $\begin{array}{c}\text { Animal } \\
\text { Allergens }\end{array}$ & Foods & Other \\
\hline $\begin{array}{l}\text { A: Bencard }(2 \cdot 5 \% w / v) \\
\text { Mixed grass } \\
\text { Mixed spring flowers } \\
\text { Mixed summer flowers } \\
\text { Mixed shrubs } \\
\text { Mixed trees }\end{array}$ & $\begin{array}{l}\text { Sheep wool } \\
\text { Cat fur } \\
\text { Dog fur }\end{array}$ & $\begin{array}{l}\text { Fish } \\
\text { Eggs } \\
\text { Milk }\end{array}$ & Mixed moulds \\
\hline
\end{tabular}

B: Dome

House dust (5000 protein nitrogen units $/ \mathrm{ml}$ )

Dermatophagoides culinae (1500 protein nitrogen units/ml)

\section{Results}

Serum IgE concentrations in asthmatic children. Of the 237 children studied, 116 $(49 \%)$ were found to have serum concentrations of IgE over 1000 units $/ \mathrm{ml}$. The IgE concentrations divided by intervals of 1000 units $/ \mathrm{ml}$ are shown in Fig. 3. Those with IgE concentrations of over 900 units $/ \mathrm{ml}$ as opposed to 1000 units $/ \mathrm{ml}$, are, however, referred to hereinafter as the high IgE group and comparisons made above and below this level, because 900 units $/ \mathrm{ml}$ is the threshold at which levels can be reliably measured and this concentration lies nearer to $+2 \mathrm{SD}$ above the mean for middle and late childhood (Johansson, 1968; Berg and Johansson, 1969a). The remainder, in whom the serum concentrations did not exceed 900 units/ml, are referred to as the normal IgE

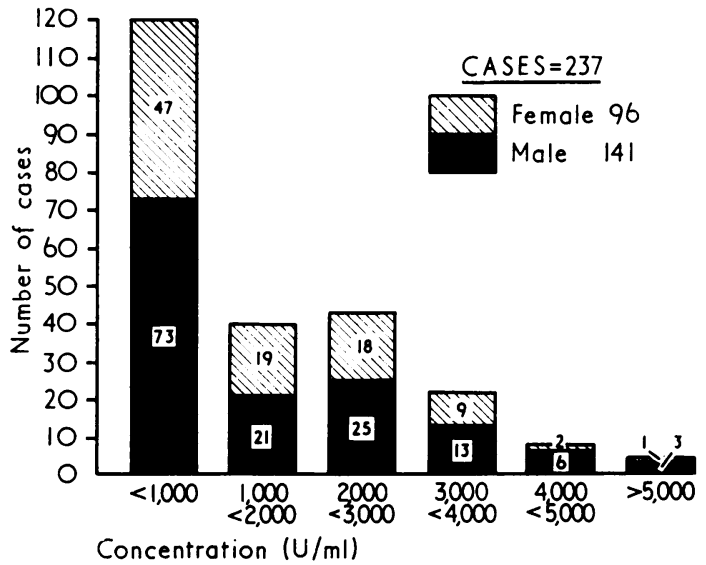

FIG. 3.-Distribution of serum IgE concentrations in asthmatic children.

group, though it is realized that some children in the group have somewhat raised levels especially because the normal range in early childhood is lower than in adults. In both groups there were approximately one-and-a-half times as many boys as girls.

IgE concentrations in nonasthmatic patients. In 63 nonasthmatic patients the concentration of $\mathrm{IgE}$ was found to be over 900 units $/ \mathrm{ml}$ in only 6 and their diagnoses are shown in Table III; none of the remaining 58 nonasthmatic patients had similar diagnoses.

\section{TABLE III}

Diagnosis of Nonasthmatic Patients with Raised Serum IgE Concentration

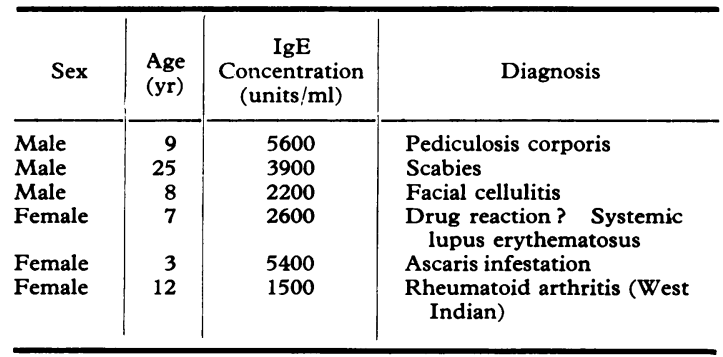

Stability of IgE on storage and thawing. IgE determinations were repeated, after thawing and freezing to $-20^{\circ} \mathrm{C}$ six times, on 18 serum samples initially found to have concentrations over 900 units $/ \mathrm{ml}$. The concentration measured in all samples decreased and the average for all the 18 
TABLE IV

Repeated IgE Determination in Same Patients (2 or more bleeds between December 1968 and January 1971)

\begin{tabular}{|c|c|c|c|c|c|}
\hline IgE Concentration (units/ml) & $>900$ & $<900$ & Rose $>900$ & Fell $<900$ & Other \\
\hline $\begin{array}{l}\text { Number } \\
\text { Average number of sera per patient examined in each group } \\
\text { Mean IgE concentration (readings over } 900 \text { units } / \mathrm{ml} \text { ) }\end{array}$ & $\begin{array}{l}22 \\
2 \cdot 36 \\
2700\end{array}$ & $\begin{array}{l}18 \\
2 \cdot 38 \\
-\end{array}$ & $\begin{array}{r}5 \\
2 \cdot 8 \\
1200\end{array}$ & $\begin{array}{l}4 \\
2 \cdot 75 \\
2000\end{array}$ & $\begin{array}{l}1 \\
3^{\star}\end{array}$ \\
\hline
\end{tabular}

$\star$ Rose above and then fell below 900 units $/ \mathrm{ml}$.

fell from 2700 units/ml to 1500 units/ml, indicating a considerable decay of $\operatorname{IgE}$ determinant involved in precipitation with anti-IgE.

Results of repeated sampling from same patients. Because higher IgE concentrations have been reported in summer than in spring and winter (Berg and Johansson, 1969b), repeated samples were examined from 50 children at various times of the year, in order to assess whether the high and normal IgE groups were stable enough to permit comparison of their other characteristics. In 10 out of 50 the IgE concentrations either rose above or fell below 900 units/ml (Table IV), but in the remaining 40, levels either stayed over 900 units $/ \mathrm{ml}$ or under 900 units $/ \mathrm{ml}$.

The $95 \%$ confidence limits (with continuity correction) for this more stable combined group (40 cases) are 34-46 out of a sample of 50 , or $68-92 \%$. It is important to note that the proportions of patients with IgE concentrations either above and/or below 900 units/ml (22 and 18) were very similar to those in the whole sample of 236 , and that those repeatedly sampled were almost all between 5 and 10 years old. Children with past or present eczema predominated in the stable high IgE group.

IgE concentrations in relation to occurrence of eczema. Eczema was present or had occurred in the past in $119(50 \%)$ of the children studied. Among those who had never had eczema $35 \%$ had levels of $\mathrm{IgE}$ over 1000 units/ml (Fig. 4), but in those with past or present eczema the group with IgE concentration of over 1000 units $/ \mathrm{ml}$ comprised $65 \%$ (Fig. 5). IgE concentration was not necessarily related to the extent, severity, or acuteness of the eczema. The sex distribution of raised IgE level was not influenced by the occurrence of eczema.

Age and sex variation. The relative though not total stability of the groups with concentrations

\footnotetext{
^Discrimination at 1000 units $/ \mathrm{ml}$ rather than $900 \mathrm{units} / \mathrm{ml}$ is made here in order to make Fig. 4 and 5 comparable to Fig. 3.
}

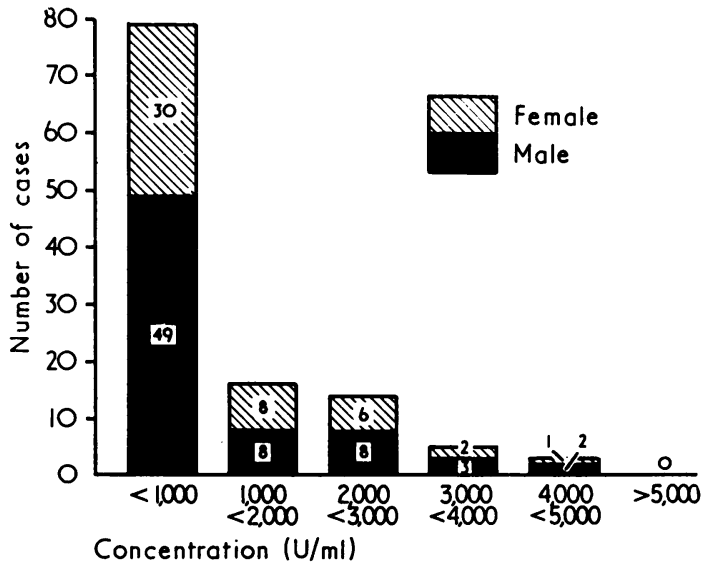

FIG. 4.-Distribution of IgE concentrations in children with asthma alone.

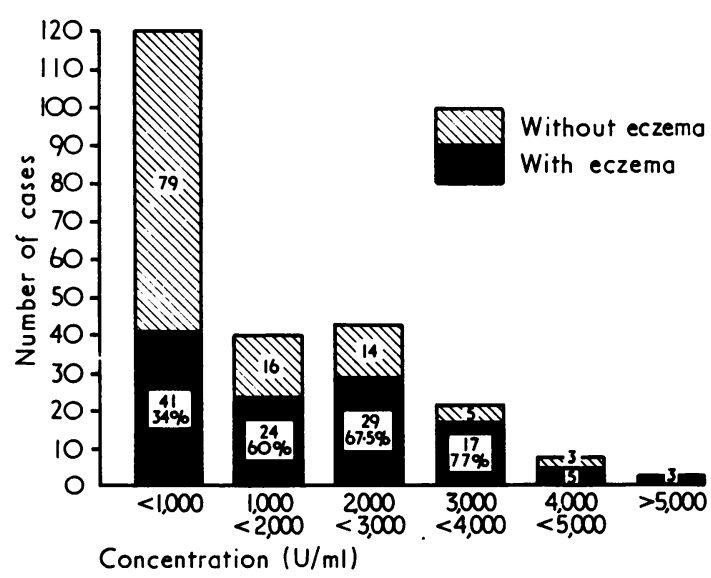

FIG. 5.-IgE concentration in asthma: proportion with active or past eczema, sexes combined.

above and below 900 units/ml made it justifiable to compare IgE concentrations, and the proportion with high and low levels, by age and sex, using under 5 years, 5 and under 10, 10 and under 15 years as class markers (Fig. 6).

Among children under 5 years old, the promi- 


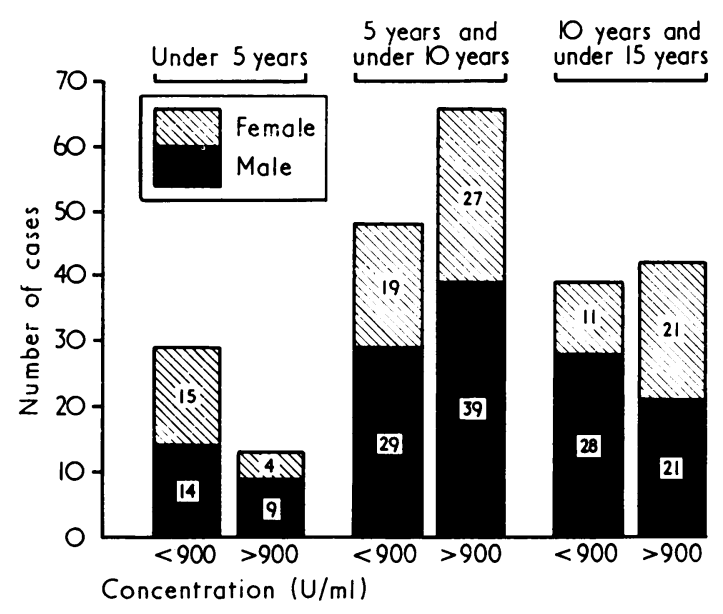

FIG. 6.-Age and sex distribution of asthmatic children with serum IgE concentrations above or below 900 units $/ \mathrm{ml}$.

nence of males, which applies to asthma as a whole, is accentuated in the high IgE group. With sexes combined the proportion with high IgE concentration was significantly greater $\left(\chi^{2}=7 \cdot 5 ; \mathrm{P}<0.01\right.$ 1 d.f.) in the age group 5 to 10 years when compared with the under 5 years. In all age groups the mean IgE concentration in the high IgE group was found to be higher for males than females, but the differences between the means were not significant (Table V).

\section{TABLE V}

Raised IgE Concentration-Mean Levels by Age and Sex

\begin{tabular}{l|c|c|c}
\hline & $<5$ years & $\begin{array}{c}>5 \text { years and } \\
<10 \text { years }\end{array}$ & $\begin{array}{c}>10 \text { years and } \\
<15 \text { years }\end{array}$ \\
\hline Boys & $2100(9)$ & $\begin{array}{l}2500(27) \\
2100(27)\end{array}$ & $\begin{array}{l}2600(21) \\
2400(20)\end{array}$ \\
Girls & $1300(3)$ & \\
\hline
\end{tabular}

Note: Number of children shown in brackets. Four West Indian children have been omitted from the calculation.

Skin tests. Of the 111 who were skin tested, only 8 were found to be completely nonreactive to the range of antigens used. With the exception of 2, all the nonreactors had IgE concentrations less than 900 units $/ \mathrm{ml}$. Sensitivity to grass pollens, house dust, and Dermatophagoides culinae was more common than to other antigens. In the groups aged 5 to 10 and 10 to 15 years, nonreactors were less frequent than in the very young. A higher percentage of children reacted to each of the antigen mixtures in the high IgE group than in the normal IgE group which, nevertheless, included a con- siderable number of positive reactors (Table VI). The average number of separate antigen mixtures to which sensitivity could be shown in each child was significantly greater in the high IgE group than in the normal IgE group (Table VII).

\section{TABLE VI \\ Percentages of Children with Positive Skin Tests Divided by IgE Level}

\begin{tabular}{|c|c|c|}
\hline & IgE $<900$ units $/ \mathrm{ml}$ & IgE $>900$ units $/ \mathrm{ml}$ \\
\hline $\begin{array}{l}\text { Mixed shrub pollens } \\
\text { Mixed grass pollens } \\
\text { Mixed tree pollens } \\
\text { Mixed flower pollens } \\
\text { Mixed house dust } \\
\text { House dust mite } \\
\quad \text { (Dermatophagoides } \\
\text { culinae) }\end{array}$ & $\begin{array}{l}11 \cdot 9 \% \\
62 \% \\
7 \cdot 1 \% \\
4 \cdot 8 \% \\
57 \% \\
\\
48 \%\end{array}$ & $\begin{array}{l}19 \cdot 5 \% \\
74 \% \\
24 \% \\
15 \% \\
67 \cdot 5 \%\end{array}$ \\
\hline
\end{tabular}

Note: Very few children reacted to the mixed mould extract.

TABLE VII

Average Number of Positive Skin Tests per Child

\begin{tabular}{|c|c|c|}
\hline & $\begin{array}{c}5 \text { years and } \\
<10\end{array}$ & $\begin{array}{c}10 \text { years and } \\
<15\end{array}$ \\
\hline $\begin{array}{l}\text { IgE concentration }>900 \text { units } / \mathrm{ml} \\
\text { IgE concentration }<900 \text { units } / \mathrm{ml}\end{array}$ & $\begin{array}{l}3 \cdot 33^{\star} \\
2 \cdot 26\end{array}$ & $\begin{array}{l}3 \cdot 2^{\star} \\
2 \cdot 32\end{array}$ \\
\hline $\begin{array}{l}\mathrm{t}= \\
\mathrm{z}=\end{array}$ & $\begin{array}{l}2 \cdot 40^{\star} \\
0 \cdot 49 t\end{array}$ & $\begin{array}{l}2 \cdot 48^{\star} \\
0 \cdot 47\end{array}$ \\
\hline
\end{tabular}

^Significant at $5 \%$ level (Student's ' $t$ ' test).

† Significant at $2 \%$ level (Wilcoxon's rank-sum test).

\section{Discussion}

The study now reported is comparable with those of (1) Berg and Johansson (1969b) in which IgE concentrations were measured in 94 children with atopic disease, (2) of Kumar et al. (1971) who made observations on 117 asthmatic children at the Children's Asthma Research Institute and Hospital, Denver, Colorado, and (3) of Hogarth-Scott et al. (1971) who studied 170 asthmatic children in Melbourne. However, in these three studies reference was not made to the same research standard, and measurements were expressed in $\mathrm{ng} / \mathrm{ml}$. Berg and Johansson (1969b) used the highly sensitive radio immunosorbant method originally used for IgE determination by Johansson and Bennich (1967), but Hogarth-Scott et al. (1971) and Kumar et al. (1971) used a modification of single radial diffusion using ${ }^{131}$ I-labelled second antibody, similar to that described by Rowe (1969). In the series of Kumar et al. (1971) only 30 of 116 cases were found to have levels over $700 \mathrm{ng} / \mathrm{ml}$ which was regarded by the authors as the level 
dividing normal from abnormally high IgE concentrations. Berg and Johansson (1969b) found 45 out of 94 atopic children had raised levels. Hogarth-Scott et al. (1971) found a much lower incidence of raised levels. Both Berg and Johansson (1969b) and Kumar et al. (1971) have drawn attention to the higher levels of IgE which are found in children with eczema and perennial asthma when compared with children with asthma alone. Our findings are in accord with this though we have expressed them in a different way.

The high levels of IgE recorded in atopic disease must be presumed to result from higher than normal synthesis of IgE, the mechanism of which is unknown. It is not yet clear whether the groups with high and normal IgE concentration represent opposite ends of a continuous distribution or whether each is a separate subpopulation.

Among the nonasthmatics with high IgE concentration, those with pediculosis corporis and scabies were of special interest, since it is possible that the high levels of $\operatorname{IgE}$ found resulted from percutaneous sensitization. Ascaris infestation has previously been associated with raised IgE levels (Johansson, Mellbin, and Vahlquist, 1968). IgE antibodies have been reported in drug sensitivity (Korotzer and Haddad, 1970) and though it cannot be proved that the 7-year-old girl reported here, who had a severe systemic lupus-like illness shortly after the introduction of sulphadimidine and pyrimethamine, had $\operatorname{IgE}$ antibodies against these drugs, the rise in serum IgE was short lived, and subsided with her recovery.

Against the background of relative stability of high and normal IgE groups, a developmental pattern for the immunological disorder in childhood asthma has been sought. Our findings suggest that in the under 5-year-old asthmatics it is more common for IgE concentration to be within the normal range, but in middle childhood (5 to 10 years) high levels of IgE are more likely to be found. In late childhood and early adolescence, balance between high and normal IgE groups was restored. In all three age groups, the mean IgE concentration in the high IgE group tended to be higher in boys than in girls, which contrasts with the higher IgM levels known to occur in girls as compared with boys (Butterworth, McClellan, and Allansmith, 1967).

The subsample whose skin tests are reported was restricted to 111 in order to maintain standards of uniformity of method, antecedent drug therapy, etc. The use of antigen mixtures was unavoidable, since in young children it was essential to provide comprehensive screening using the minimum number of prick tests. It is interesting to note that the small group that was nonreactive to the antigen used was closely comparable in size to that which was negative to allergy testing in Berg and Johansson's series (1969b). The significantly higher number of skin tests we found in the high IgE groups confirm in a very simple way the original findings of Wide, Bennich, and Johansson (1967) who, using particle adsorbed allergens, found that the mean IgE level in patients sensitive to one allergen was $633 \mathrm{ng} / \mathrm{ml}$, and $1307 \mathrm{ng} / \mathrm{ml}$ in those sensitive to two or more. The small fraction of cases who were nonreacting diminished in late childhood.

Other clinical characteristics-height, weight, respiratory function, pattern of symptoms-are now being investigated and compared in the low and high IgE groups.

We thank Dr. D. S. Rowe and Dr. S. G. O. Johansson for advice and encouragement; Dr. Rowe for kindly supplying reagents; Professor N. Butler and paediatricians of the United Bristol Hospitals for referring cases; and Action for the Crippled Child for support.

REFERENCES

Berg, T., and Johansson, S. G. O. (1969a). Immunoglobulin levels during childhood, with special regard to IgE. Acta Paediatrica Scandinavica, 58, 513.

Berg, T., and Johansson, S. G. O. (1969b). IgE concentration in children with atopic diseases. International Archives of Allergy and Applied Immunology, 36, 219.

Butterworth, M., McClellan, B., and Allansmith, M. (1967) Influence of sex on immunoglobulin levels. Nature (London), 214, 1224.

Hogarth-Scott, R. S., Howlett, B. J., McNicol, K. N., Simons, M. J., and Williams, H. E. (1971). IgE levels in the sera of asthmatic children. Clinical and Experimental Immunology, $\mathbf{9}, 571$.

Ishizaka, K., Ishizaka, T., and Hornbrook, M. M. (1966). Physicochemical properties of human reaginic antibody. IV. The presence of a unique immunoglobulin as a carrier of reaginic activity. Fournal of Immunology, 97, 75.

Johansson, S. G. O. (1968). Serum IgND levels in healthy children and adults. International Archives of Allergy and Applied Immunology, 34, 1.

Johansson, S. G. O., and Bennich, H. (1967). Studies on a new class of human immunoglobulins. I. Immunological properties. In 3rd Nobel Symposium. The Gamma Globulins, p. 193. Ed. by J. Killander. Almqvist and Wiksell, Stockholm.

Johansson, S. G. O., Bennich, H., and Wide, L. (1968). A new class of immunoglobulin in human serum. Immunology, 14, 265.

Johansson, S. G. O., Mellbin, T., and Vahlquist, B. (1968). Immunoglobulin levels in Ethiopian pre-schoolchildren with special reference to high concentration of immunoglobulin E (IgND). Lancet, 1, 1118 .

Korotzer, J., and Haddad, Z. H. (1970). In vitro detection of human IgE-mediated immediate hypersensitivity reactions to pollens and penicillins by a modified rat mast cell degranulation technique. (Abst.) Fournal of Allergy, 45, 126.

Kumar, L., Newcomb, R. W., Ishizaka, K., Middleton, E., and Hornbrook, M. M. (1971). IgE levels in sera of children with asthma. Pediatrics, 47, 848.

Mancini, G., Carbonara, A. O., and Heremans, J. F. (1965). Immunochemical quantitation of antigens by single radial immunodiffusion. Immunochemistry, 2, 235.

Rowe, D. S. (1969). Radioactive single radial diffusion. Bulletin of the World Health Organization, 40, 613. 
Rowe, D. S., Tackett, L., Bennich, H., Ishizaka, K., Johansson, S. G. O., and Anderson, S. G. (1970). A research standard tor human serum immunoglobulin E. Bulletin of the World Health Organization, 43, 609.

Rowe, D. S., and Wood, C. B. S. (1970). The measurement of serum immunoglobulin $\mathrm{E}$ levels in healthy adults, and children, and in children with allergic asthma. International Archives of Allergy and Applied Immunology, 39, 1.
Wide, L., Bennich, H., and Johansson, S. G. O. (1967). Diagnosis of allergy by an in-vitro test for allergen antibodies. Lancet, 2, 1105 .

Correspondence to Professor C. B. S. Wood, Department of Child Health, Queen Elizabeth Hospital for Children, Hackney Road, London E2 8PS.

\section{International Society for Paediatric Neurosurgery}

On 7 May 1972, The International Society for Paediatric Neurosurgery was formed. The pro tem officers are: Dr. Jacques Rougerie (President), Dr. Anthony J. Raimondi (Secretary), and Dr. Joseph Ransohoff (Treasurer).

Requests for membership should be directed to: Dr. Maurice Choux, Département de Neuro-Chirurgie, Centre Hospitalier et Universitaire, Hôpital Nord, Marseille 15, France.

The first scientific meeting will be held in conjunction with the World Federation of Neurosurgical Societies, in Tokyo, Japan, in 1973. For details concerning the meeting write to: Dr. Satoshi Matsumoto, Kobe University, Chairman, Department of Neurosurgery, 12 Kusumoki-cho 7 Chome, Ikuta-ku, Kobe, Japan. 